\title{
Tobacco Chemistry 64*. A New Sucrose Ester from Greek Tobacco
}

\author{
Inger Wahlberg, ${ }^{a}$ E. Brian Walsh, ${ }^{a}$ Ingrid Forsblom, ${ }^{a}$ Stefan Oscarson, ${ }^{a}$ \\ Curt R. Enzell, ${ }^{a}$ Ragnar Ryhage ${ }^{b}$ and Roland Isaksson ${ }^{c}$
}

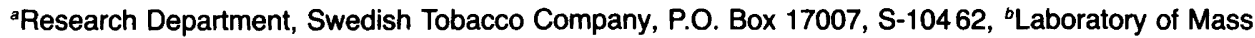
Spectrometry, Karolinska Institute, P.O. Box 60400, S-10401 Stockholm, and 'Division of Organic Chemistry 3, Chemical Center, University of Lund, P.O. Box 124, S-221 00 Lund, Sweden

\begin{abstract}
Wahlberg, Inger, Walsh, Brian E., Forsblom, Ingrid, Oscarson, Stefan, Enzell, Curt R., Ryhage, Ragnar and Isaksson, Roland., 1986. Tobacco Chemistry 64. A New Sucrose Ester from Greek Tobacco. - Acta Chem. Scand. B 40: 724-730.

A new sucrose ester has been isolated from Greek tobacco and shown to be 6-Oacetyl-2,3,4-tri- $O-[-3 S$-methylpentanoyl]-sucrose (1) by spectral methods and chemical correlation.
\end{abstract}

It is well established that tobaccos of the oriental type differ chemically from Virginia and Burley tobaccos in several respects. They have a higher proportion of certain low molecular weight fatty acids such as 3-methylpentanoic acid $^{2}$ and contain, in addition to cembranoids, diterpenoids of the labdane class. ${ }^{3}$ The genetic differences between these tobacco varieties are apparently also reflected in the content of certain sugars. Thus, 6-O-acetyl-2,3,4-tri- $O$-[3S-methylpentanoyl]- $\beta$ D-glycopyranose $(2)^{4}$ and a few related glucose esters have been isolated from Turkish tobacco. ${ }^{5}$ Moreover, analytical studies, employing gas chromatography after conversion to silyl ethers ${ }^{6,7}$ or direct chemical ionization mass spectrometry, ${ }^{8}$ have shown that oriental tobaccos contain up to $0.2 \%$ of sucrose esters, whereas considerably lower levels are detected in Virginia and Burley tobaccos.

Although available results suggest that these sucrose esters are substituted on the glucose moiety with one unit of acetic acid and three units of $\mathrm{C}_{3}-\mathrm{C}_{8}$ fatty acids, ${ }^{6-8}$ unambigous structural evidence has not, as yet, been presented. We now report the isolation and structure determination of one of these sucrose esters (1).

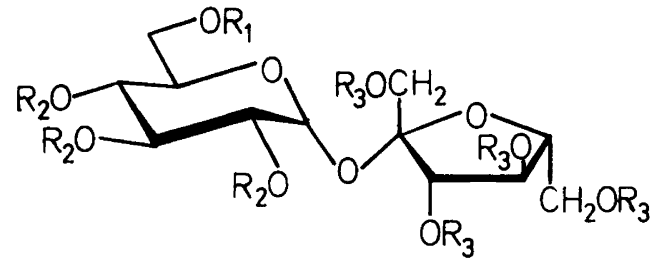

$1 R_{1}=A c, R_{2}=3$ S-methylpentanoyl, $R_{3}=H$

$3 R_{1}=R_{3}=A c, R_{2}=3$ S-methylpentanoyl

$4 R_{1}=R_{2}=R_{3}=A C$

$5 \quad R_{1}=R_{2}=R_{3}=H$

${ }^{*}$ For part 63, see Ref. 1 .

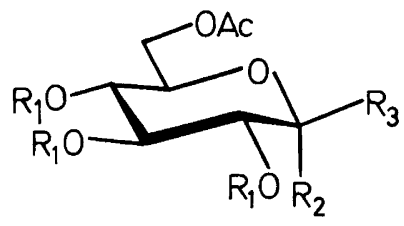

$R_{1}=3 \underline{S}-$ methylpentanoyl

$2 \mathrm{R}_{2}=\mathrm{H}, \mathrm{R}_{3}=\mathrm{OH}$

$6 \mathrm{R}_{2}=\mathrm{OH}, \mathrm{R}_{3}=\mathrm{H}$

$10 \mathrm{R}_{2}=\mathrm{H}, \mathrm{R}_{3}=\mathrm{OAC}$

$9 \quad R_{2}=O A c, R_{3}=H$

724 Acta Chemica Scandinavica B 40 (1986) $\quad 724-730$ 


\section{Results}

The new compound ( 1 ) was identified as a disaccharide from the ${ }^{13} \mathrm{C}$ NMR spectrum (Table 1), which contained twelve signals in the region $60<$ $\delta<105$. It is a monoacetate $\left({ }^{1} \mathrm{H}\right.$ NMR singlet at $\delta 2.11$ ) converted to a pentaacetate (3) on acetylation. In contrast to 1,3 gave a ${ }^{1} \mathrm{H}$ NMR spectrum amenable to detailed analysis. This was carried out by using the results obtained from COSY spectra and spin simulation studies.

A comparison of the ${ }^{1} \mathrm{H}$ chemical shift values and coupling constants (Table 2) and the ${ }^{13} \mathrm{C}$ NMR data (Table 1) for 3 with the corresponding values for sucrose octaacetate (4) strongly suggested that 3 was a sucrose derivative. This assignment was verified by sugar analysis of 1 , which gave glucose and fructose. The ${ }^{13} \mathrm{C}$ NMR spectrum of the new compound (1) also exhibited signals at $\delta 170.7,171.8,172.5$ and 173.0 consonant with the presence of four ester groups. While one of these was the aforementioned acetate group, the chemical shift values and multiplicities of the remaining signals in the ${ }^{13} \mathrm{C} N M R$ spectrum indicated that the other three ester groups each contained six carbon atoms. Empirical calculations and comparison with data of relevant reference compounds showed that the observed resonances were consistent only with the occurrence of three 3-methylpentanoyl groups. This conclusion was verified and the 3methylpentanoic component ascribed a $3 S$ chirality after isolation of the acidic fraction from an alkaline hydrolysate of 1 .

A comparison of the ${ }^{13} \mathrm{C}$ NMR spectra of 1 and its peracetylated derivative 3 to those of sucrose octaacetate $(4)^{9}$ and sucrose $(5)^{10}$ suggested that the most likely positions of esterification were on the pyranose ring, but an exact assignment was not possible by this means. However, as $6-O$ acetyl-2,3,4-tri- $O$-[3S-methylpentanoyl]- $\beta$-D-glucopyranose (2) has been isolated from tobacco, ${ }^{4}$ it seemed biogenetically most plausible that the new compound (1) was 6-O-acetyl-2,3,4-tri- $O$ [-3S-methylpentanoyl]-sucrose. This structural assignment was strongly corroborated by the FAB mass spectrum, which contained a peak at $\mathrm{m} / \mathrm{z} 701$, ascribed to the $[\mathrm{M}+\mathrm{Na}]^{+}$ion, and a base peak at $\mathrm{m} / \mathrm{z} 99$ due to a 3-methylpentanoyl ion (cf. Scheme 1). A diagnostic ion of mass 499 $\left(\mathrm{C}_{26} \mathrm{H}_{43} \mathrm{O}_{9}\right.$ from high resolution EI-MS), which as indicated in Scheme 1, undergoes sequential loss of three 3-methylpentanoyl units and one molecule of acetic acid, probably comprised the tetraesterified pyranose ring. Complementary to this, was the presence of a peak at $m / z 163$, which was attributed to the unsubstituted furanose ring and appropriately shifted to $\mathrm{m} / z 331$ in the spectrum of the pentaacetate 3 .

Structural evidence was sought by chemical methods. Thus, acid-catalyzed hydrolysis of 1 using trifluoroacetic acid yielded the $\alpha$ - and $\beta$-anomers of a glucose tetraester $(6,2)$. Although the $\beta$-anomer had m.p. and optical rotation in good agreement with those reported ${ }^{4}$ for $6-O$-acetyl$2,3,4$-tri- $O$-[3S-methylpentanoyl]- $\beta$-D-glucopyranose (2), it was felt that a comparison based solely on these data would not suffice for an unequivocal structural assignment. The chemical correlation shown in Scheme 2 was therefore carried out, whereby 1,6 -anhydro- $\beta$-D-glycopyranose (7) was converted to the 2,3,4-triester 8 by treatment with $3 S$-methylpentanoyl chloride, a reagent obtained via preparative enantiomer separation of ( \pm )-benzyl 3-methylpentanoate on swollen microcrystalline triacetylcellulose. The triester 8 was subjected to acetolysis, which gave a mixture of the $\alpha$ - and $\beta$-anomers of 1,6-di- $O$-acetyl-2,3,4tri- $O$-[ $3 S$-methylpentanoyl]-D-glucopyranose $(9$, 10). These were identical in all respects to the diacetates obtained from the hydrolysis products 6 and 2 , respectively, hence conclusively assigning a 6-O-acetyl-2,3,4-tri- $O$-[3S-methylpentanoyl]sucrose structure to the new tobacco constituent 1. A different method for the allocation of the various fatty acid residues in sucrose ester 1 involving long range $\mathrm{C}-\mathrm{H}$ shift correlation spectroscopy was also applied and will be described elsewhere. ${ }^{11}$

\section{Experimental}

The FAB mass spectra were recorded on an LKB 2091 instrument equiped with an Iontech FAB$11 \mathrm{NF}$ unit. Xenon atoms of $6 \mathrm{keV}$ energy were used in the bombardment. The sample holder and ion source were kept at room temperature; the samples were dissolved in glycerol. Other instrumental details are given in Ref. 1.

Sugar analysis was carried out by Dr L. Kenne at the Department of Organic Chemistry, Stockholm University using conventional methods. An extract $(83 \mathrm{~g})$, obtained by immersing flowers of Greek Nicotiana tabacum (Basma Drama) in 
chloroform, was initially separated into five fractions, A-E, by flash chromatography (silica gel, hexane/ethyl acetate/methanol as eluents). Part $(1.20 \mathrm{~g})$ of the most polar fraction $(\mathrm{E}, 3.6 \mathrm{~g})$ was further separated by reverse phase HPLC, using columns packed with $\mu$-Bondapak/C18 and Spherisorb 5 ODS, to give $30.3 \mathrm{mg}$ of $6-O$-acetyl2,3,4-tri- $O$-[3S-methylpentanoyl]-sucrose $(1)$ as a gum, which had $[\alpha]_{\mathrm{D}}+51^{\circ}(c \quad 0.26$, EtOH) (Found: $[\mathrm{M}+\mathrm{Na}]^{+}$701. Calc. for $\mathrm{C}_{32} \mathrm{H}_{54} \mathrm{O}_{15} \mathrm{Na}$ : 701); IR $\left(\mathrm{CHCl}_{3}\right)$ bands at 3364, 3028, 2966, 2931, 2878, 1744, 1454, 1383, 1267, 1235, 1179, and $1136 \mathrm{~cm}^{-1} ;{ }^{1} \mathrm{H}$ NMR $\left(\mathrm{CDCl}_{3}\right): \delta \quad 0.8-1.0$ (18H, overlapping signals, $3 \times \mathrm{CH}_{3} \mathrm{CH}_{2} \mathrm{CH}\left(\mathrm{CH}_{3}\right)$ $\left.\mathrm{CH}_{2}-\right)$, 1.1-1.5 $(6 \mathrm{H}$, overlapping signals, $\left.3 \times \mathrm{CH}_{3} \mathrm{CH}_{2} \mathrm{CH}\left(\mathrm{CH}_{3}\right) \mathrm{CH}_{2}-\right)$, 1.7-2.0 (3H, overlapping signals, $3 \times \mathrm{CH}_{3} \mathrm{CH}_{2} \mathrm{CH}\left(\mathrm{CH}_{3}\right) \mathrm{CH}_{2}-$ ), 2.0-2.5 $\quad(6 \mathrm{H}, \quad$ overlapping signals, $\left.3 \times \mathrm{CH}_{3} \mathrm{CH}_{2} \mathrm{CH}\left(\mathrm{CH}_{3}\right) \mathrm{CH}_{2}-\right), \quad 2.11 \quad(3 \mathrm{H}, \quad \mathrm{s}$, $\left.-\mathrm{OCOCH}_{3}\right), 2.8(1 \mathrm{H}$, broad s, $-\mathrm{OH}), 3.1(1 \mathrm{H}$, broad $\mathrm{s},-\mathrm{OH}), 3.5-4.0(7 \mathrm{H}$, overlapping signals, $\mathrm{H}-1^{\prime}, \mathrm{H}-5^{\prime}, \mathrm{H}-6^{\prime}$, and $\left.2 \times-\mathrm{OH}\right), 4.1-4.5$ (5H, overlapping signals, $\mathrm{H}-5, \mathrm{H}-6, \mathrm{H}-3^{\prime}$, and $\mathrm{H}-4^{\prime}$ ), 4.91 (dd, $J=4.0$ and $10.3 \mathrm{~Hz}, \mathrm{H}-2$ ), $5.10(\mathrm{dd}, J=9.5$ and $10.2 \mathrm{~Hz}, \mathrm{H}-4), 5.53$ (dd, $J$ $=9.5$ and $10.3 \mathrm{~Hz}, \mathrm{H}-3), 5.72(\mathrm{~d}, J=4.0 \mathrm{~Hz}$,
$\mathrm{H}-1)$; MS, FAB [m/z (\%)]: $701(\mathrm{M}+\mathrm{Na}, 3), 499$ (4), 457 (0.7), $401(2), 383(0.4), 359(0.3), 341$ (0.6), 303 (0.6), 285 (1), 267 (0.6), 261 (3), 243 (2), 205 (3), 169 (8), 163 (5), 145 (8), 127 (14), 115 (26), and $99(100)$; MS, EI $[\mathrm{m} / z(\%$, composition)]: $499\left(1, \mathrm{C}_{26} \mathrm{H}_{43} \mathrm{O}_{9}\right), 401\left(2, \mathrm{C}_{20} \mathrm{H}_{33} \mathrm{O}_{8}\right)$, $303\left(3, \mathrm{C}_{14} \mathrm{H}_{23} \mathrm{O}_{7}\right), 285\left(1, \mathrm{C}_{14} \mathrm{H}_{21} \mathrm{O}_{6}\right), 261(5$, $\left.\mathrm{C}_{12} \mathrm{H}_{21} \mathrm{O}_{6}\right), 243\left(1, \mathrm{C}_{12} \mathrm{H}_{19} \mathrm{O}_{5}\right), 205\left(1, \mathrm{C}_{8} \mathrm{H}_{13} \mathrm{O}_{6}\right)$, $169\left(3, \mathrm{C}_{8} \mathrm{H}_{9} \mathrm{O}_{4}\right), 163\left(0.4, \mathrm{C}_{6} \mathrm{H}_{11} \mathrm{O}_{5}\right), 145(1$, $\left.\mathrm{C}_{6} \mathrm{H}_{9} \mathrm{O}_{4}\right), 127\left(4, \mathrm{C}_{6} \mathrm{H}_{7} \mathrm{O}_{3}\right), 115\left(2, \mathrm{C}_{5} \mathrm{H}_{7} \mathrm{O}_{3}\right.$ and $\left.\mathrm{C}_{6} \mathrm{H}_{11} \mathrm{O}_{2}\right), 99\left(100, \mathrm{C}_{6} \mathrm{H}_{11} \mathrm{O}\right.$ and $\left.\mathrm{C}_{5} \mathrm{H}_{7} \mathrm{O}_{2}\right), 71(51$, $\mathrm{C}_{5} \mathrm{H}_{11}$ and $\left.\mathrm{C}_{3} \mathrm{H}_{3} \mathrm{O}_{2}\right)$, and $43\left(73, \mathrm{C}_{3} \mathrm{H}_{7}\right.$ and $\mathrm{C}_{2} \mathrm{H}_{3} \mathrm{O}$ ).

Preparation of $1^{\prime}, 3^{\prime}, 4^{\prime}, 6,6^{\prime}$-penta-O-acetyl-2,3,4tri-O-[3S-methylpentanoyl]-sucrose (3). A solution of $5 \mathrm{mg}$ of $1 \mathrm{in} 2 \mathrm{ml}$ of $\mathrm{Ac}_{2} \mathrm{O}$-pyridine (1:1) was kept at room temp. overnight. After workup, $5 \mathrm{mg}$ of 2 was obtained as an oil, which had $[\alpha]_{\mathrm{D}}+46^{\circ}(c \mathrm{0.26}, \mathrm{EtOH})$; IR $\left(\mathrm{CHCl}_{3}\right): 3018$, 2965, 2929, 2857, 1745, 1461, 1370, 1232, 1175, 1151, 1093, and $1057 \mathrm{~cm}^{-1} ;{ }^{1} \mathrm{H}$ NMR $\left(\mathrm{CDCl}_{3}\right): \delta$ $0.80-0.95 \quad(18 \mathrm{H}, \quad$ overlapping signals, $\left.3 \times \mathrm{CH}_{3} \mathrm{CH}_{2} \mathrm{CH}\left(\mathrm{CH}_{3}\right) \mathrm{CH}_{2}-\right)$, 1.1-1.4 $(6 \mathrm{H}$, overlapping signals $\left.3 \times \mathrm{CH}_{3} \mathrm{CH}_{2} \mathrm{CH}\left(\mathrm{CH}_{3}\right) \mathrm{CH}_{2}-\right), 1.7-$

Table 1. ${ }^{13} \mathrm{C}$ NMR chemical shifts and assignments for compounds $1-6,9$ and $10 .^{a}$

\begin{tabular}{llllllllllllll}
\hline $\begin{array}{l}\text { Com- } \\
\text { pound }\end{array}$ & 1 & 2 & 3 & 4 & 5 & 6 & $1^{\prime}$ & $2^{\prime}$ & $3^{\prime}$ & $4^{\prime}$ & $5^{\prime}$ & $6^{\prime}$ \\
\hline $1^{c}$ & 89.2 & 70.6 & 69.2 & 67.7 & 68.9 & 61.6 & $60.5^{b}$ & 104.8 & 78.8 & 73.7 & 82.0 & $64.8^{b}$ \\
$3^{c, d}$ & 89.8 & 70.2 & 69.0 & 67.8 & 68.7 & 61.8 & 63.1 & 103.8 & 75.4 & 74.6 & 79.0 & 63.4 \\
$4^{9}$ & 89.9 & 70.3 & 69.6 & 68.2 & 68.5 & 61.8 & 62.9 & 104.0 & 75.7 & 75.0 & 79.1 & 63.6 \\
$5^{10}$ & 92.9 & 72.0 & 73.6 & 70.2 & 73.3 & 61.1 & 63.3 & 104.4 & 77.4 & 75.0 & 82.2 & 63.4 \\
$6^{c}$ & 90.2 & $71.2^{b}$ & $69.1^{b}$ & 67.5 & $68.1^{b}$ & 62.0 & & & & & & \\
$2^{c}$ & 95.9 & $73.3^{b}$ & $72.3^{b}$ & 68.1 & $71.3^{b}$ & 62.1 & & & & & & \\
$9^{c}$ & 89.0 & $69.9^{b}$ & $69.2^{b}$ & 67.5 & $69.1^{b}$ & 61.6 & & & & & & \\
$10^{c}$ & 91.8 & 69.9 & $72.9^{b}$ & 67.5 & $72.1^{b}$ & 61.6 & & & & & & \\
\hline
\end{tabular}

a $\delta$ Values in $\mathrm{CDCl}_{3}$ relative to TMS; 5 was recorded in $\mathrm{D}_{2} \mathrm{O}$. ${ }^{b}$ Assignment may be reversed.

$\left.{ }^{\circ} \mathrm{OCOCH} \mathrm{CH}_{2} \mathrm{CH} \mathrm{CH}_{3}\right) \mathrm{CH}_{2} \mathrm{CH}_{3}$ and $\mathrm{OCOCH}_{3} ; \delta 170.7,171.8,172.5$, and 173.0 for $1 ; \delta 169.7,169.9,170.0,170.5$, $170.7,171.7,172.1$, and 172.4 for $3 ; \delta 170.8,171.9,172.1$, and 172.5 for $6 ; \delta 170.7,172.1$, and 173.7 for $2 ; \delta$ 168.7, 170.6, 171.6, 171.9, and 172.2 for $9 ; \delta 169.0,170.6,171.4,171.6$, and 172.1 for 10;

$\mathrm{OCOCH}_{2} \mathrm{CH}\left(\mathrm{CH}_{3}\right) \mathrm{CH}_{2} \mathrm{CH}_{3}: \delta 40.9,41.0$ and 41.1 for $1 ; \delta 40.8,41.0$, and 41.1 for 3; $\delta 41.1$, and 41.2 for $6 ; \delta$

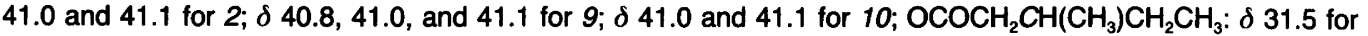
1 and $3 ; \delta 31.5,31.6$, and 31.7 for $6 ; \delta 31.6$ and 31.7 for $2 ; \delta 31.5$ and 31.6 for $9 ; \delta 31.4,31.5$, and 31.7 for

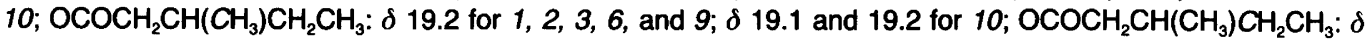
29.1 and 29.2 for 1,9 , and $10 ; \delta 29.2$ for 2, 3, and 6; $\mathrm{OCOCH}_{2} \mathrm{CH}\left(\mathrm{CH}_{3}\right) \mathrm{CH}_{2} \mathrm{CH}_{3}: \delta 11.2$ for 1, 2, 3, 6, and 10; $\delta 11.1$ and 11.2 for $9 ; \mathrm{OCOCH}_{3}: \delta 20.7$ for 1 and $3 ; \delta 20.8$ for 2,6 , and $10 ; \delta 20.7$ and 20.9 for 9 . ${ }^{\circ}$ The spectrum was recorded under WALTZ-16 conditions. ${ }^{13}$ Because of the presence of several degenerate peaks and the occurrence of a wide range of ${ }^{1} J_{C, H}$ values, a two-dimensional heteronuclear $J$ method was applied to facilitate the determination of the multiplicities of the lines in the spectrum of $3 .^{14}$ 
$1.9 \quad(3 \mathrm{H}, \quad$ overlapping signals, $\left.3 \times \mathrm{CH}_{3} \mathrm{CH}_{2} \mathrm{CH}\left(\mathrm{CH}_{3}\right) \mathrm{CH}_{2}-\right), \quad 2.10 \quad(6 \mathrm{H}, \quad$ s, $\left.2 \times-\mathrm{OCOCH}_{3}\right), 2.11\left(3 \mathrm{H}, \mathrm{s},-\mathrm{OCOCH}_{3}\right), 2.12$ $\left(3 \mathrm{H}, \mathrm{s},-\mathrm{OCOCH}_{3}\right), 2.18\left(3 \mathrm{H}, \mathrm{s},-\mathrm{OCOCH}_{3}\right)$, 2.0-2.4 $\quad(6 \mathrm{H}, \quad$ overlapping signals, $\left.3 \times \mathrm{CH}_{3} \mathrm{CH}_{2} \mathrm{CH}\left(\mathrm{CH}_{3}\right) \mathrm{CH}_{2}-\right)$, 4.1-4.4 (8H, overlapping signals, $\mathrm{H}-5, \mathrm{H}-6, \mathrm{H}-1^{\prime}, \mathrm{H}-5^{\prime}$, $\mathrm{H}-6^{\prime}$ ), 4.90 (dd, $J=3.7$ and $10.4 \mathrm{~Hz}, \mathrm{H}-2$ ), 5.13 (dd, $J=9.6$ and $10.1 \mathrm{~Hz}, \mathrm{H}-4), 5.39$ (dd, $J$ $=5.9$ and $\left.6.0 \mathrm{~Hz}, \mathrm{H}-4^{\prime}\right), 5.46(\mathrm{~d}, J=6.0 \mathrm{~Hz}$, $\left.\mathrm{H}-3^{\prime}\right), 5.50$ (dd, $J=9.6$ and $10.4 \mathrm{~Hz}, \mathrm{H}-3$ ), and $5.70(\mathrm{~d}, J=3.7 \mathrm{~Hz}, \mathrm{H}-1)$; MS, FAB $[\mathrm{m} / z(\%)]$ : 869 (M+Na, 0.4), 499 (5), 401 (0.5), $383(0.4)$, 331 (30), 303 (0.4), 289 (3), 285 (0.9), 243 (5), 211 (37), 169 (55), 127 (13), 109 (47), and 99 (100).

A. Hydrolysis of 6-O-acetyl-2,3,4-tri- $O$-[3Smethylpentanoyl]-sucrose (1). A solution of 100 $\mathrm{mg}$ of 1 in $5 \mathrm{ml}$ of ethanol and $0.5 \mathrm{ml}$ of aqueous $\mathrm{KOH}(45 \%)$ was kept at room temp. for $5 \mathrm{~h}$. The reaction mixture was diluted with water, acidified using aqueous $\mathrm{H}_{2} \mathrm{SO}_{4}(10 \%)$ and extracted with $\mathrm{Et}_{2} \mathrm{O}$. The organic phase was dried and the $\mathrm{Et}_{2} \mathrm{O}$ carefully removed by distillation. The residue having $[\alpha]_{\mathrm{D}}+5^{\circ}\left(c \mathrm{0.5}, \mathrm{CHCl}_{3}\right)$ gave a ${ }^{1} \mathrm{H}$ NMR spectrum showing the presence of acetic and 3methylpentanoic acid.

B. Hydrolysis of 6-O-acetyl-2,3,4-tri- $O-[3 S$ methylpentanoyl]-sucrose (1). To $50 \mathrm{mg}$ of 1 was added $2 \mathrm{ml}$ of aqueous trifluoroacetic acid
$(90 \%)$. The solution was kept at room temperature for $25 \mathrm{~min}$., diluted with toluene and evaporated to give $55 \mathrm{mg}$ of a residue. This was separated by HPLC using a column packed with $\mu$ Bondapak/CN and ethyl acetate/hexane (30:70) as the eluent to give $23 \mathrm{mg}$ of $6-O$-acetyl-2,3,4tri- $O$-[3S-methylpentanoyl]- $\alpha$-D-glucopyranose (6) and $7 \mathrm{mg}$ of 6-O-acetyl-2,3,4-tri- $O-[3 S$ methylpentanoyl]- $\beta$-D-glucopyranose (2). The former, (6), was amorphous and had $[\alpha]_{\mathrm{D}}+72^{\circ}(c$ $\left.0.2, \mathrm{CHCl}_{3}\right)$; IR $\left(\mathrm{CHCl}_{3}\right): 3597,3460,2967,2933$, $2880,1746,1461$, and $1383 \mathrm{~cm}^{-1} ;{ }^{1} \mathrm{H}$ NMR $\left(\mathrm{CDCl}_{3}\right): \delta 0.8-1.0(18 \mathrm{H}$, overlapping signals, $\left.3 \times \mathrm{CH}_{3} \mathrm{CH}_{2} \mathrm{CH}\left(\mathrm{CH}_{3}\right) \mathrm{CH}_{2}-\right), 1.1-1.4(6 \mathrm{H}$, overlapping signals, $\left.3 \times \mathrm{CH}_{3} \mathrm{CH}_{2} \mathrm{CH}\left(\mathrm{CH}_{3}\right) \mathrm{CH}_{2}-\right)$, 1.7-2.0 (3H, overlapping signals, $3 \times \mathrm{CH}_{3} \mathrm{CH}_{2}$ $\left.\mathrm{CH}\left(\mathrm{CH}_{3}\right) \mathrm{CH}_{2}-\right), 2.0-2.4(6 \mathrm{H}$, overlapping signals, $\left.3 \times \mathrm{CH}_{3} \mathrm{CH}_{2} \mathrm{CH}\left(\mathrm{CH}_{3}\right) \mathrm{CH}_{2}-\right), 2.10 \quad(\mathrm{~s}$, $\left.-\mathrm{OCOCH}_{3}\right), 2.90($ broad s, $-\mathrm{OH}), 4.14(\mathrm{dd}, J=$ 2.6 and $-12.3 \mathrm{~Hz}, \mathrm{H}-6 \mathrm{a}), 4.19$ (dd, $J=4.0$ and $-12.3 \mathrm{~Hz}, \mathrm{H}-6 \mathrm{~b}), 4.26$ (ddd, $J=2.6,4.0$, and $10.1 \mathrm{~Hz}, \mathrm{H}-5), 4.89$ (dd, $J=3.1$ and $10.1 \mathrm{~Hz}$, $\mathrm{H}-2), 5.13(\mathrm{t}, J=10.1 \mathrm{~Hz}, \mathrm{H}-4), 5.50(\mathrm{dd}, J=$ 3.1 and $4 \mathrm{~Hz}, \mathrm{H}-1)$ and $5.60(\mathrm{t}, J=10.1 \mathrm{~Hz}$, $\mathrm{H}-3)$; MS, EI $[\mathrm{m} / \mathrm{z}(\%)]: 499(\mathrm{M}-17,0.1), 469$ (0.1), $442(0.2), 401(0.6), 354(0.5), 285(0.5)$, 269 (3), 256 (4), 200 (1), 169 (2), 99 (100), 71 (33), and 43 (31). The latter, (2), had m.p. 104 $107^{\circ} \mathrm{C} ;[\alpha]_{\mathrm{D}}+30^{\circ}\left(c 0.2, \mathrm{CHCl}_{3}\right)$, reported m.p. $104-106^{\circ} \mathrm{C} ;[\alpha]_{\mathrm{D}}+30.2^{\circ}$ (c $\left.4.7, \mathrm{CHCl}_{3}\right) ;{ }^{4} \mathrm{IR}$

Table 2. Chemical shift values and coupling constants for the protons of the sucrose moieties of 3 and $4 .^{a}$

\begin{tabular}{lllll}
\hline & 3 & \multicolumn{2}{c}{$4^{15.16}$} \\
\hline $\mathrm{H}-1$ & $5.93 \mathrm{~d}$ & $(3.7 \mathrm{~Hz})$ & $5.86 \mathrm{~d}$ & $(3.7 \mathrm{~Hz})$ \\
$\mathrm{H}-2$ & $5.12 \mathrm{dd}$ & $(3.7$ and $10.5 \mathrm{~Hz})$ & $5.03 \mathrm{dd}$ & $(3.7$ and $10.4 \mathrm{~Hz})$ \\
$\mathrm{H}-3$ & $5.96 \mathrm{dd}$ & $(9.6$ and $10.5 \mathrm{~Hz})$ & $5.82 \mathrm{dd}$ & $(9.4$ and $10.4 \mathrm{~Hz})$ \\
$\mathrm{H}-4$ & $5.47 \mathrm{dd}$ & $(9.6$ and $10.4 \mathrm{~Hz})$ & $5.38 \mathrm{dd}$ & $(9.4$ and $10.3 \mathrm{~Hz})$ \\
$\mathrm{H}-5$ & $4.61 \mathrm{ddd}$ & $(2.3,4.5 \mathrm{and} 10.4 \mathrm{~Hz})$ & $4.51 \mathrm{ddd}$ & $(2.6,4.2$ and $10.3 \mathrm{~Hz})$ \\
$\mathrm{H}-6 \mathrm{a}$ & $4.45 \mathrm{dd}$ & $(2.3$ and $-12.4 \mathrm{~Hz})$ & $4.36 \mathrm{dd}$ & $(2.6 \mathrm{and}-12.3 \mathrm{~Hz})$ \\
$\mathrm{H}-6 \mathrm{~b}$ & $4.49 \mathrm{dd}$ & $(4.5 \mathrm{and}-12.4 \mathrm{~Hz})$ & $4.41 \mathrm{dd}$ & $(4.2 \mathrm{and}-12.3 \mathrm{~Hz})$ \\
$\mathrm{H}-1^{\prime} \mathrm{a}$ & $4.33 \mathrm{~d}$ & $(-12.2 \mathrm{~Hz})$ & $4.29 \mathrm{~d}$ & $(-12.4 \mathrm{~Hz})$ \\
$\mathrm{H}-1^{\prime} \mathrm{b}$ & $4.40 \mathrm{~d}$ & $(-12.2 \mathrm{~Hz})$ & $4.36 \mathrm{~d}$ & $(-12.4 \mathrm{~Hz})$ \\
$\mathrm{H}-3^{\prime}$ & $5.77 \mathrm{~d}$ & $(5.8 \mathrm{~Hz})$ & $5.70 \mathrm{~d}$ & $(5.5 \mathrm{~Hz})$ \\
$\mathrm{H}-4^{\prime}$ & $5.62 \mathrm{dd}$ & $(5.8$ and $5.9 \mathrm{~Hz})$ & $5.54 \mathrm{t}$ & $(5.5 \mathrm{~Hz})$ \\
$\mathrm{H}-5^{\prime}$ & $4.22 \mathrm{dt}$ & $(4.5 \mathrm{and} 5.9 \mathrm{~Hz})$ & $4.19 \mathrm{dt}$ & $(5.4 \mathrm{and} 5.5 \mathrm{~Hz})$ \\
$\mathrm{H}-6^{\prime} \mathrm{a}$ & $4.43 \mathrm{dd}$ & $(4.5 \mathrm{and}-12.0 \mathrm{~Hz})$ & $4.40 \mathrm{~d}$ & $(5.4 \mathrm{~Hz})$ \\
$\mathrm{H}-66^{\prime} \mathrm{b}$ & $4.46 \mathrm{dd}$ & $(5.9$ and $-12.0 \mathrm{~Hz})$ & &
\end{tabular}

as Values in $\mathrm{C}_{6} \mathrm{D}_{6}$ relative to TMS. Multiplicities are indicated by the usual symbols: $d$, doublet; dd, doublet of doublets; ddd, doublet of doublets of doublets; $t$, triplet; dt, doublet of triplets. Figures in parenthesis are coupling constants. 


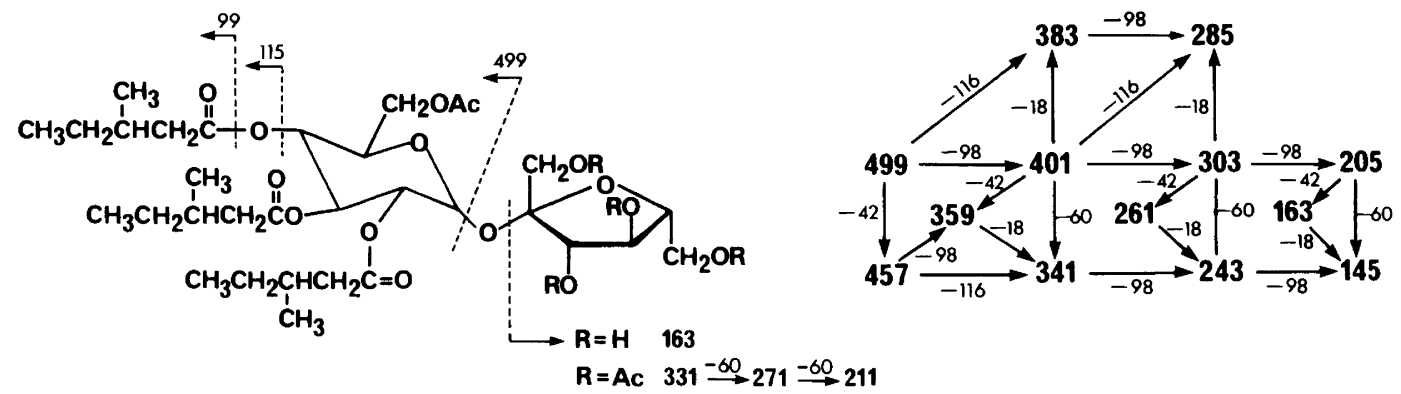

Scheme 1.

$\left(\mathrm{CHCl}_{3}\right): 3600,3465,2967,2932,2878,1746$, 1461 , and $1382 \mathrm{~cm}^{-1} ;{ }^{1} \mathrm{H}$ NMR $\left(\mathrm{CDCl}_{3}\right): \delta 0.8-1.0$ $(18 \mathrm{H}, \quad$ overlapping signals, $\left.3 \times \mathrm{CH}_{3} \mathrm{CH}_{2} \mathrm{CH}\left(\mathrm{CH}_{3}\right) \mathrm{CH}_{2}-\right), 1.1-1.4(6 \mathrm{H}$, overlapping signals, $\left.3 \times \mathrm{CH}_{3} \mathrm{CH}_{2} \mathrm{CH}\left(\mathrm{CH}_{3}\right) \mathrm{CH}_{2}-\right)$, 1.7-2.0 (3H, overlapping signals, $\left.3 \times \mathrm{CH}_{3} \mathrm{CH}_{2} \mathrm{CH}\left(\mathrm{CH}_{3}\right) \mathrm{CH}_{2}-\right), 2.0-2.4(6 \mathrm{H}$, overlapping signals, $\left.3 \times \mathrm{CH}_{3} \mathrm{CH}_{2} \mathrm{CH}\left(\mathrm{CH}_{3}\right) \mathrm{CH}_{2}-\right)$, $2.10\left(\mathrm{~s},-\mathrm{OCOCH}_{3}\right), 3.57(\mathrm{~d}, \mathrm{~J}=9.2 \mathrm{~Hz},-\mathrm{OH})$, 3.74 (ddd, $J=2.6,4.6$, and $10.0 \mathrm{~Hz}, \mathrm{H}-5$ ), 4.16 (dd, $J=2.6$ and $-12.3 \mathrm{~Hz}, \mathrm{H}-6 \mathrm{a}), 4.20$ (dd, $J=$ 4.6 and $-12.3 \mathrm{~Hz}, \mathrm{H}-6 \mathrm{~b}), 4.72$ (dd, $J=8.9$ and $9.2 \mathrm{~Hz}, \mathrm{H}-1), 4.89(\mathrm{dd}, J=8.9$ and $9.8 \mathrm{~Hz}$, $\mathrm{H}-2$ ), 5.13 (dd, $J=9.7$ and $10.0 \mathrm{~Hz}, \mathrm{H}-4$ ) and 5.33 (dd, $J=9.7$ and $9.8 \mathrm{~Hz}, \mathrm{H}-3$ ); MS, EI $[\mathrm{m} / \mathrm{z}$ (\%)]: 499 (M-17, 0.1), 469 (0.2), $442(0.3), 401$ (0.8), 354 (0.6), $285(0.5), 269$ (3), 256 (4), 200 (1), $169(2), 99(100), 71(33)$, and 43 (31).

MS, FAB of a mixture of the $\alpha$ and $\beta$ anomers $[\mathrm{m} / \mathrm{z}(\%)]: 517(\mathrm{M}+\mathrm{H}, 0.2), 499(8), 401(4), 383$ (0.5), 341 (0.3), 303 (0.5), 285 (1), 169 (8), 127 (3), $109(9), 99$ (100), 71 (74), and 43 (53).

Preparation of 1,6-anhydro-2,3,4-tri-O-[3Smethylpentanoyl]- $\beta$-D-glucopyranose (8). A solution of $0.11 \mathrm{~g}$ of benzyl $3 S$-methylpentanoate in 2 $\mathrm{ml}$ of ethanol and $1 \mathrm{ml}$ of $\mathrm{KOH}$ (aqueous, $25 \%$ ) was stirred at room temperature for $10 \mathrm{~min}$. Dichloromethane was added, and the acid extracted with aqueous $\mathrm{NaOH}(1 \mathrm{M})$. The aqueous phase was acidified and extracted with $\mathrm{Et}_{2} \mathrm{O}$, the $\mathrm{Et}_{2} \mathrm{O}$ phase washed and concentrated to give crude $3 S$ methylpentanoic acid. Without further purification, this acid was dissolved in $0.5 \mathrm{ml}$ of dichloromethane and treated with $50 \mu \mathrm{l}$ of $\mathrm{SOCl}_{2}(1.2$ equiv.). After stirring for $1 \mathrm{~h}, 20 \mathrm{mg}$ of 1,6 -anhydro- $\beta$-D-glucopyranose (7) dissolved in $0.5 \mathrm{ml}$ of pyridine were added. After an additional 30 min, the reaction mixture was applied to the top of a silica gel column and eluted with ethyl acetate/hexane (20:80) to give $39 \mathrm{mg}$ of 1,6-anhydro2,3,4-tri- $O$-[ $3 S$-methylpentanoyl]- $\beta$-D-glucopyranose $(8)$ as a syrup, $[\alpha]_{\mathrm{D}}-28^{\circ}\left(\mathrm{c} 0.7, \mathrm{CHCl}_{3}\right)$; IR $\left(\mathrm{CHCl}_{3}\right): 2967,2933,2879,1734,1461,1382$, $1287,1241,1176,1151,1121,1097,1046$, and $1025 \mathrm{~cm}^{-1} ;{ }^{1} \mathrm{H}$ NMR $\left(\mathrm{CDCl}_{3}\right): \delta 0.85-1.0(18 \mathrm{H}$, overlapping signals, $\left.3 \times \mathrm{CH}_{3} \mathrm{CH}_{2} \mathrm{CH}\left(\mathrm{CH}_{3}\right) \mathrm{CH}_{2}-\right)$, 1.2-1.5 $\quad(6 \mathrm{H}, \quad$ overlapping signals, $\left.3 \times \mathrm{CH}_{3} \mathrm{CH}_{2} \mathrm{CH}\left(\mathrm{CH}_{3}\right) \mathrm{CH}_{2}-\right), 1.8-2.0(3 \mathrm{H}$, overlapping signals, $\left.3 \times \mathrm{CH}_{3} \mathrm{CH}_{2} \mathrm{CH}\left(\mathrm{CH}_{3}\right) \mathrm{CH}_{2}-\right)$, 2.1-2.5 (6H, overlapping signals, $\left.3 \times \mathrm{CH}_{3} \mathrm{CH}_{2} \mathrm{CH}\left(\mathrm{CH}_{3}\right) \mathrm{CH}_{2}-\right), 3.81$ (dd, $J=5.4$ and $-7.8 \mathrm{~Hz}, \mathrm{H}-6 \mathrm{a}), 4.10$ (dd, $J=1.0$ and -7.8 $\mathrm{Hz}, \mathrm{H}-6 \mathrm{~b}$ ), 4.55-4.65 (overlapping signals, $\mathrm{H}-2, \mathrm{H}-4$, and $\mathrm{H}-5), 4.86(\mathrm{~m}, \mathrm{H}-3)$, and 5.46 (m, $\mathrm{H}-1)$.

Acetolysis of 1,6-anhydro-2,3,4-tri-O-[3S-methylpentanoyl $]-\beta$-D-glucopyranose (8). To a solution of $38 \mathrm{mg}$ of $8 \mathrm{in} 1 \mathrm{ml}$ of $\mathrm{Ac}_{2} \mathrm{O}$ was added $0.1 \mathrm{ml}$ of $\mathrm{Ac}_{2} \mathrm{O} / \mathrm{H}_{2} \mathrm{SO}_{4}\left(1 \% \mathrm{H}_{2} \mathrm{SO}_{4}\right)$. After $15 \mathrm{~min}$ at room temperature, water and dichloromethane were added to the reaction mixture. The organic phase was washed with aqueous $\mathrm{NaHCO}_{3}$ and water and concentrated to yield $38 \mathrm{mg}$ of an oil. This was separated by HPLC (Spherisorb 5 CN, ethyl acetate/hexane $10: 90$ ) to give $28 \mathrm{mg}$ of 1,6 -di- $O$ acetyl-2,3,4-tri- $O$-[3S-methylpentanoyl]- $\alpha$-D-glucopyranose (9) and $6 \mathrm{mg}$ of 1,6-di- $O$-acetyl-2,3,4tri- $O$-[ $3 S$-methylpentanoyl]- $\beta$-D-glucopyranose (10). The former, (9), had m.p. $60-62^{\circ} \mathrm{C} ;[\alpha]_{\mathrm{D}}$ $+80^{\circ}$ (c 0.3, EtOH); IR $\left(\mathrm{CCl}_{4}\right): 2966,2929,2877$, $1755,1455,1369,1224,1175,1154,1120,1091$, 1031, 1011, and $938 \mathrm{~cm}^{-1} ;{ }^{1} \mathrm{H}$ NMR $\left(\mathrm{CDCl}_{3}\right): \delta$ 0.8-1.0 $\quad(18 \mathrm{H}, \quad$ overlapping signals, $\left.3 \times \mathrm{CH}_{3} \mathrm{CH}_{2} \mathrm{CH}\left(\mathrm{CH}_{3}\right) \mathrm{CH}_{2}-\right), 1.1-1.4(6 \mathrm{H}$, overlapping signals, $\left.3 \times \mathrm{CH}_{3} \mathrm{CH}_{2} \mathrm{CH}\left(\mathrm{CH}_{3}\right) \mathrm{CH}_{2}-\right)$, 1.7-1.9 $\quad(3 \mathrm{H}, \quad$ overlapping signals, 

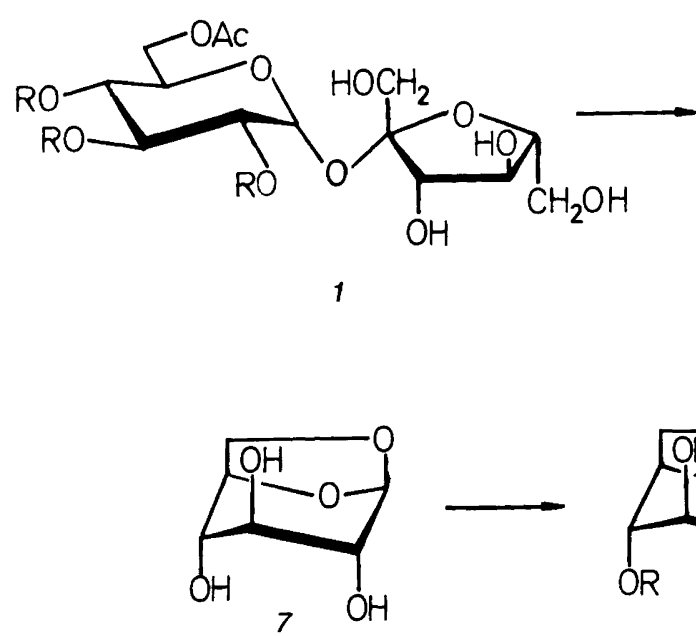
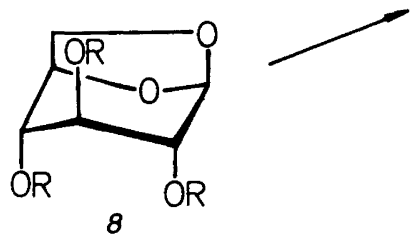

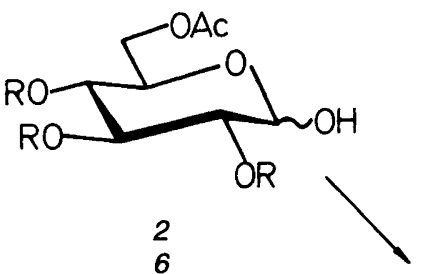

6

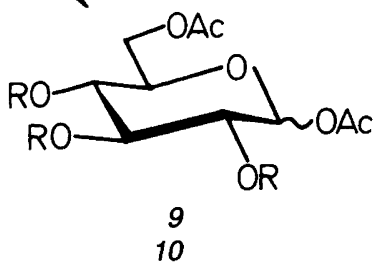

$\mathrm{R}=3$ S-methylpentanoyl

Scheme 2.

$\left.3 \times \mathrm{CH}_{3} \mathrm{CH}_{2} \mathrm{CH}\left(\mathrm{CH}_{3}\right) \mathrm{CH}_{2}-\right), 2.0-2.4(6 \mathrm{H}$, overlapping signals, $3 \times \mathrm{CH}_{3} \mathrm{CH}_{2} \mathrm{CH}\left(\mathrm{CH}_{3}\right) \mathrm{CH}_{2}-$ ), $2.10\left(\mathrm{~s},-\mathrm{OCOCH}_{3}\right), 2.17\left(\mathrm{~s},-\mathrm{OCOCH}_{3}\right), 4.05-$ 4.3 (overlapping multiplets, $\mathrm{H}-5, \mathrm{H}-6 \mathrm{a}$ and $\mathrm{H}-6 \mathrm{~b}$ ), 5.09 (dd, $J=3.7$ and $10.3 \mathrm{~Hz}, \mathrm{H}-2$ ), $5.19(\mathrm{dd}, J=9.6$ and $9.7 \mathrm{~Hz}, \mathrm{H}-4), 5.54(\mathrm{dd}, J=$ 9.6 and $10.3 \mathrm{~Hz}, \mathrm{H}-3)$, and $6.35(\mathrm{~d}, J=3.7 \mathrm{~Hz}$, $\mathrm{H}-1)$; MS, EI [m/z (\%)]: $515(\mathrm{M}-43,0.3), 499$ (1), 442 (1), 354 (2), 301 (0.7), 285 (0.6), 269 (3), 256 (5), 196 (2), 169 (4), 109 (3), 99 (100), 71 (34), 57 (5), and $43(38)$.

The latter, $(10)$, had m.p. $80-81^{\circ} \mathrm{C} ;[\alpha]_{\mathrm{D}}+7^{\circ}(\mathrm{c}$ 0.3, EtOH); IR $\left(\mathrm{CCl}_{4}\right): 2966,2931,2878,1755$, $1461,1382,1367,1218,1178,1150,1119,1079$, 1013, and $907 \mathrm{~cm}^{-1} ;{ }^{1} \mathrm{H}$ NMR $\left(\mathrm{CDCl}_{3}\right): \delta 0.8-1.0$ $(18 \mathrm{H}, \quad$ overlapping signals, $\left.3 \times \mathrm{CH}_{3} \mathrm{CH}_{2} \mathrm{CH}\left(\mathrm{CH}_{3}\right) \mathrm{CH}_{2}-\right), 1.1-1.4(6 \mathrm{H}$, overlapping signals, $3 \times \mathrm{CH}_{3} \mathrm{CH}_{2} \mathrm{CH}\left(\mathrm{CH}_{3}\right) \mathrm{CH}_{2}-$ ), 1.7-1.9 $(3 \mathrm{H}, \quad$ overlapping signals, $\left.3 \times \mathrm{CH}_{3} \mathrm{CH}_{2} \mathrm{CH}\left(\mathrm{CH}_{3}\right) \mathrm{CH}_{2}-\right), 2.0-2.4(6 \mathrm{H}$, overlapping signals, $3 \times \mathrm{CH}_{3} \mathrm{CH}_{2} \mathrm{CH}\left(\mathrm{CH}_{3}\right) \mathrm{CH}_{2}-$ ), $2.09\left(6 \mathrm{H}, \mathrm{s}, 2 \times-\mathrm{OCOCH}_{3}\right), 3.83$ (ddd, $J=2.4$, 4.5 and $9.6 \mathrm{~Hz}, \mathrm{H}-5$ ), 4.13 (dd, $J=2.4$ and $-12.5 \mathrm{~Hz}, \mathrm{H}-6 \mathrm{a}), 4.21$ (dd, $J=4.5$ and -12.5 $\mathrm{Hz}, \mathrm{H}-6 \mathrm{~b}$ ), 5.17 (dd, $J=9.3$ and $9.6 \mathrm{~Hz}, \mathrm{H}-4$ ), $5.17(\mathrm{dd}, J=7.9$ and $9.3 \mathrm{~Hz}, \mathrm{H}-2), 5.30(\mathrm{t}, J=$ $9.3 \mathrm{~Hz}, \mathrm{H}-3)$, and $5.72(\mathrm{~d}, J=7.9 \mathrm{~Hz}, \mathrm{H}-1)$; MS EI [ $/ \mathrm{m} / \mathrm{z}(\%)]: 515(\mathrm{M}-43,0.3) 499(0.2), 442$ (0.8), 354 (2), 327 (0.6), 301 (0.6), 284 (1), 269 (2), $256(6), 196(2), 169(3), 109(2), 99(100), 71$ (36), 57 (5), and $43(38)$.
Acetylation of 6-O-acetyl-2,3,4-tri-O-[3S-methylpentanoyl]-D-glucopyranose ( 6 and 2 ). A solution of $20 \mathrm{mg}$ of a mixture of 6 and $2 \mathrm{in} 2 \mathrm{ml}$ of $\mathrm{Ac}_{2} \mathrm{O} /$ pyridine (1:1) was kept at room temperature for $1 \mathrm{~h}$. After dilution with toluene and concentration at reduced pressure, the reaction mixture was purified by flash chromatography over silica gel to give $18 \mathrm{mg}$ of mixture. This was separated by HPLC (Spherisorb $5 \mathrm{CN}$; ethyl acetate/hexane, 10:90) into two diacetates, which were identical in all respects (m.p., mixed m.p., optical rotation, IR, ${ }^{1} \mathrm{H}$ NMR and MS) to the $\alpha$ - and $\beta$ anomers of 1,6-di- $O$-acetyl-2,3,4-tri- $O$-[3Smethylpentanoyl]-D-glucopyranose 9 and 10 , respectively.

Preparative enantiomer separation of $( \pm)$-benzyl 3-methylpentanoate. Methods for the preparation of the triacetylated cellulose and the columns as well as the instrumental details have been described elsewhere. ${ }^{12}$ The sample of ( \pm )-benzyl 3methylpentanoate was dissolved in ethanol/water (95:5), and an injection volume of $4 \mathrm{ml}$ was used for $\sim 100 \mathrm{mg}$ of the ester. Due to the poor separation (separation factor $\sim 1.35$ ), the ester had to be cycled nine times through the columns. After each cycle, the $(+)$ enantiomer was depleted of the $(-)$ enantiomer. The fractions collected were concentrated to give in all $\sim 10 \mathrm{mg}$ of the $(+)$ enantiomer, which was virtually $100 \%$ pure as determined by NMR technique $\left(\mathrm{CDCl}_{3} ; \mathrm{Eu}\right.$ (hfbc) $)_{3}$. 
Acknowledgements. We are grateful to Dr. Petra Ossowski-Larsson and Mr. Jacek Bielawski for recording the mass spectra and to Dr. Toshiaki Nishida for recording the NMR spectra. We are also indebted to Dr. Petra Ossowski-Larsson and Dr. Toshiaki Nishida for fruitful advice and discussion.

\section{References}

1. Wahlberg, I., Arndt, R., Nishida, T. and Enzell, C. R. Acta Chem. Scand. B 40 (1986) 123.

2. Stedman, R. L. Chem. Rev. 68 (1968) 153.

3. Colledge, A., Reid, W. W. and Russell, R. Chem. Ind. (1975), 570.

4. Schumacher, J. N. Carbohydr. Res. 13 (1970) 1.

5. Rivers, J. M. 35th Tobacco Chemists' Research Conference, Winston-Salem, North Carolina, USA (1981).

6. Severson, R. F., Arrendale, R. F., Chortyk, O. T., Johnson, A. W., Jackson, D. M., Gwynn, G. R., Chaplin, J. F. and Stephenson, M. G. J. Agric. Food Chem. 32 (1984) 566.
7. Severson, R. F., Arrendale, R. F., Chortyk, O. T., Green, G. R., Thome, 'F. A., Stewart, J. L. and Johnson, A. W. J. Agric. Food Chem. 33 (1985) 870 .

8. Einolf, W. N. and Chan, W. G. J. Agric. Food Chem. 32 (1984) 785.

9. Nishida, T., Morris, G. A. and Enzell, C. R. Magn. Reson. Chem. 24 (1986) 179.

10. Pfeffer, P. E., Valentine, K. M. and Parrish, F. W. J. Am. Chem. Soc. 101 (1979) 1265.

11. Nishida, T., Morris, G. A., Forsblom, I., Wahlberg, I. and Enzell, C. R. J. Chem. Soc. Chem. Commun. (1986) 998.

12. Isaksson, R. and Roschester, J. J. Org. Chem. 50 (1985) 2519.

13. Shaka, A. J., Keeler, J. and Freeman, R. J. Magn. Reson. 53 (1983) 313.

14. Nishida, T., Enzell, C. R. and Keeler, J. J. Chem. Soc. Chem. Commun. (1985), 1489.

15. De Bruyn, A., Anteunis, M. and Verhegge, G. Carbohydr. Res. 42 (1975) 157.

16. Ikura, M. and Hickichi, K. J. Am. Chem. Soc. 106 (1984) 4275.

Received March 21, 1986. 